\title{
Creating low-cost high-resolution digital elevation models
}

\author{
M. LOUHAICHI, M.M. BORMAN, A.L. JOHNSON, AND D.E. JOHNSON
}

Authors are Graduate Research Assistant, Associate Professor, Student, and Professor, respectively. Department of Rangeland Resources, Oregon State University, Corvallis, Ore. 97331-2218, U.S.A

\section{Abstract}

Ecologists and agronomists are interested in topography because it affects soil, plant, and hydrologic processes. Digital elevation models (DEMs) accurate to several centimeters of vertical elevation are needed but construction is time consuming and expensive when traditional surveying methods are used. Carrierphase differential global positioning systems can map vertical changes in topography with root mean square errors (RMSE) of 2 to $9 \mathrm{~cm}$, but equipment is expensive $(\$ 20,000$ to $\$ 100,000)$. Coarse-acquisition code differential global positioning systems (C/A code-DGPS) are much cheaper $(<\$ 8,000)$ and widely available but vertical errors are large with root mean square errors of 100 to $200 \mathrm{~cm}$, which severely limits their usefulness in ecological studies. We combined a coarse-acquisition code differential global positioning system and a laser level $(<\$ 1,000)$ to map topographic change in fields, wetlands, and research plots. Our technique uses the coarse-acquisition code differential global positioning system for longitudinal and latitudinal ( $X$ or easting, $Y$ or northing) position while the laser level provides vertical position (elevation) as measured from a ground control point or monument. Measuring elevation across a field scale area is a 2-step procedure. At each sample location the distance from the laser level to the ground is determined and entered as a comment in the differential global positioning systems data logger. In the office, sample locations are differentially corrected and elevation is calculated by subtracting the laser level-to-ground distance from the elevation of the laser. Data is then imported to geographic information system (GIS) software that interpolates between points. The differential global positioning system yields $X, Y$ locations with a root mean square error of between 0.5 and $1.0 \mathrm{~m}$. Elevations measured with our laser level had an accuracy of better than $2 \mathrm{~cm}$ across its $230 \mathrm{~m}$ working radius. Our technique works best for areas up to approximately 40 ha on open, rolling terrain.

Key Words: digital elevation model, DEM, digital terrain model, DTM, geographic information systems, GIS, global position system, GPS, topography

Mention of product names or corporations is for the convenience of the reade and does not constitute an official endorsement or approval by Oregon State University or the Oregon Agricultural Experiment Station of any product or service to the exclusion of others that may be suitable.

Submitted as Technical Paper No. 11789, Oregon Agricultural Experiment Station. Funding was provided by the Oregon Agricultural Experiment Station and U.S. Fish and Wildlife Service through the Oregon Agricultural Legal Foundation contract number FA 1620.

We would like to acknowledge Ward Carson, Norman Harris, and two anonymous reviewers for editorial suggestions.

Manuscript accepted 7 May 02.

\section{Resumen}

Los ecólogos y los agrónomos están interesados en la topografía porque afecta los procesos hidrológicos, el suelo y la planta. Se necesita la precisión de los modelos de elevación digital (DEMs) a varios centímetros de elevación vertical, pero la elaboración consume tiempo y es costoso cuando se utilizan métodos tradicionales de estudio. Los sistemas de posicionador global diferencial puede mapear cambios verticales en la topografía, con valores de la raíz del cuadrado medio de los errores (RMSE) de 2 a $8 \mathrm{~cm}$, pero el equipo es costoso $(\$ 20,000$ a $\$ 100,000$ dólares americanos). La adquisición gruesa (C/A) de código DGPS es mucho más barata $(<\$ 8,000$ dólares americanos) y esta disponible ampliamente, pero los errores verticales son mayores, con un RMSE de 100 a $200 \mathrm{~cm}$; el cual, limita severamente su uso en estudios ecológicos. Nosotros combinamos la $\mathrm{C} / \mathrm{A}$ de código DGPS y un nivel láser ( $<1,000$ dólares americanos) para mapear los cambios topográficos en los terrenos de cultivo, tierras húmedas y las parcelas de investigación. Nuestra técnica usa la C/A de código DGPS para la posición longitudinal y latitudinal $(\mathrm{X}, \mathrm{Y})$, mientras que el nivel láser provee la posición vertical (elevación) como medida de punto o mojón de control en el terreno. La elevación medida a través de una área en el terreno de cultivo consiste en dos procedimientos. En cada ubicación de la muestra, se determina la distancia del nivel láser al suelo, y se captura como una observación en el registrador de datos DGPS. En la oficina, las ubicaciones de las muestras se corrigen diferencialmente y se calcula la elevación por diferencia del nivel láser a la distancia al suelo, desde la elevación del láser. Luego los datos se importan a un programa de información geográfica (GIS) que hace la interpolación entre puntos. Las muestras DGPS permiten una ubicación de $X$, Y con un RMSE entre 0.5 y $1.0 \mathrm{~m}$. Las elevaciones medidas con nuestro nivel láser tuvo una certeza mayor de $2 \mathrm{~cm}$ a lo largo de los $230 \mathrm{~m}$ de radio de trabajo. Nuestra técnica funciona mejor en áreas hasta, aproximadamente, de 40 ha en terreno ondulado y abierto.

Patterns of plants, soils, and water on landscapes can be influenced by subtle changes in topography (Brady and Weil 2001, Young and Hammer 2000, Stoeckel and Miller-Goodman 2001, Brooks et al. 1997). In agronomic systems, Bakhsh et al. (2000) found that yield was influenced by topographic position within a field. Because topography and associated response patterns are spatial, geographic information systems (GIS) have been used to map and link them. Elevation or terrain models often serve as a base theme on which other data layers, such as plant community distribution, are overlain. The vertical resolution of digital elevation models (DEMs) needs to be precise enough to identify subtle differences that influence or control the pattern of vegetation and soils. Unfortunately, the most widely available digital elevation models used for natural resource/agronomic management are the 
U.S. Geological Survey (USGS) 7.5 minute digital elevation model, which is relatively imprecise in the vertical direction. The root mean square error (RMSE) is used to describe the digital elevation model accuracy and is defined as:

$$
\operatorname{RMSE}=\sqrt{\frac{\sum\left(\mathrm{Z}_{\mathrm{i}}-\mathrm{Z}_{\mathrm{t}}\right)^{2}}{\mathrm{n}}}
$$

where

$$
\begin{aligned}
\mathrm{Z}_{\mathrm{i}}= & \text { interpolated DEM elevation of a } \\
& \text { test point } \\
\mathrm{Z}_{\mathrm{t}}= & \text { true elevation of a test point } \\
\mathrm{n}= & \text { number of test points }
\end{aligned}
$$

For 7.5-minute digital elevation models derived from a photogrammetric source, $90 \%$ of control points on the ground have a vertical accuracy of $7-\mathrm{m}$ root mean square error or better and $10 \%$ are in the 8 to $15 \mathrm{~m}$ range. For 7.5 and 15 -minute digital elevation models derived from vector or digital line graph hypsographic and hydrographic source data, a root mean square error of one-half contour interval or better is required (National Mapping Division, U.S. Geological Survey 1998). This level of resolution is inappropriate for many ecological studies and for precision agriculture.

Coarse-acquisition code differential corrected global positioning system $(\mathrm{C} / \mathrm{A}$ code DGPS) technology has revolution- ized field mapping and is widely used in natural resources because $X$ (longitude) and $Y$ (latitude) position can be ascertained with a root mean square error of 50 to $100 \mathrm{~cm}$ (Trimble Navigation Ltd. 2001a). However, vertical errors of 100 to $200 \mathrm{~cm}$ are common with coarse-acquisition code differential global positioning systems (Clark and Lee 1998, Trimble Navigation Ltd. 1996). Real-time stopand-go and real-time kinematic carrierphase differential global positioning systems mounted on vehicles have been used to map boundaries (Sumpter and Asher 1994) and elevation with vertical root mean square errors reported to be from 2 to $9 \mathrm{~cm}$ (Clark and Lee 1998, Johansen et al. 2001, Trimble Navigation Ltd. 2001b, Leica Geosystems AG 1999). Carrierphase differential global positioning system units cost from $\$ 20,000$ to $\$ 100,000$ (Johansen et al. 2001). Because of the cost, carrier-phase differential global positioning systems are not as widely available as coarse-acquisition code differential global positioning systems.

Our research required a digital elevation model with vertical accuracy (root mean square error) of approximately $10 \mathrm{~cm}$ and neither a real-time stop-and-go nor realtime kinematic carrier-phase differential global positioning system was available. Therefore, we developed a method to efficiently generate highly accurate elevation models for open, relatively level land using a coarse-acquisition code differential global positioning system $(<\$ 8000)$ and a low-cost laser level $(<\$ 1000)$.

\section{Materials and Methods}

The procedure we have developed includes both data collection in the field and computer processing in the office (Table 1).

\section{Field Setup}

We collected topographic information via 2 technologies: coarse-acquisition (C/A) code differential global positioning system for the latitude (Y) and longitude (X) position and laser level with metric leveling rod for elevation (Z) (Fig. 1). We used a Trimble Navigation Pathfinder Pro $\mathrm{XR}^{\circledR}$, 12-channel, L1/CA-code differential global positioning system. With this system we can obtain an $\mathrm{X}, \mathrm{Y}$ coordinate with a root mean square error of 50 to 100 $\mathrm{cm}$ in approximately 25 seconds. The laser level system was a Laser Reference Inc. Proshot L4 ${ }^{\circledR}$ with a R4 ${ }^{\circledR}$ laser receiver and a Crain Enterprises, Inc. CR-5.0M ${ }^{\circledR}$ metric leveling rod. This laser level has a

\begin{tabular}{|c|c|}
\hline Location & Procedures \\
\hline \multirow[t]{3}{*}{ Field } & $\begin{array}{l}\text { Step 1. Identify a reference position } \\
\text { a. Locate a National Geodetic Survey Ground Control Point, or } \\
\text { b. Create a Temporary Bench Mark } \\
\text { - Phase processing RTSG }{ }^{1} \text { DGPS }^{1} \text {, or } \\
\text { - Occupy static location for an extended time }\end{array}$ \\
\hline & $\begin{array}{l}\text { Step 2: Establish the Laser Level in the Area to be Surveyed } \\
\text { a. Determine the height of the laser beam above GCP }{ }^{1} \text { using leveling rod and receiver } \\
\left.\text { b. Record the X } \mathrm{Y}^{1} \text { locations of the laser lever and laser height identification code (LHID) }\right)^{1} \text { using the GPS }{ }^{1} \text { data Logger } \\
\text { c. Enter height of the laser above the } \mathrm{GCP}^{1} \text { or } \text { TBM }^{1} \text { as a comment in the GPS }{ }^{1} \text { data logger }\end{array}$ \\
\hline & $\begin{array}{l}\text { Step 3: Start Grid Sampling } \\
\text { a. Record location X Y } \mathrm{Y}^{1} \text { using GPS }{ }^{1} \text { unit and data logger } \\
\text { b. Record height of the laser beam above the ground as a comment }\end{array}$ \\
\hline \multirow[t]{3}{*}{ Office } & $\begin{array}{l}\text { Step 4: Create Spreadsheet with } X Y Z^{1} \text { Locations } \\
\text { a. Differentially correct GPS }{ }^{1} \text { data to give } X Y^{1} \text { locations within } 1 \mathrm{~m} \\
\text { b. Subtract the height above the ground (comment) from the laser beam height to obtain the } Z^{1} \text {-value }\end{array}$ \\
\hline & $\begin{array}{l}\text { Step 5: GIS } \\
\text { a. Import data into GIS }{ }^{1} \text { software } \\
\text { b. Interpolate between points using a weighted-averaging, spline, or kriging technique, or a triangulated irregular network (TIN) }{ }^{1} \text { model }\end{array}$ \\
\hline & $\begin{array}{l}\text { Step 6: Produce Digital Elevation Models } \\
\text { a. Contour maps } \\
\text { b. } 3-D^{1} \text { maps }\end{array}$ \\
\hline
\end{tabular}
working radius of $230 \mathrm{~m}$, with a leveling accuracy of better than $2 \mathrm{~cm}$. Laser levels of this type are readily available from

Table 1. Field and office (computer) procedures for developing a digital elevation model (DEM).

${ }^{1}$ Abbreviations used are DGPS (differential global positioning system); GCP (Ground Control Point); GIS (Geographical Information System); GPS (Global Positioning System); LHID (Laser Height Identification); NGS (National Geodetic Survey); RTSG (real-time stop-and-go); TBM (temporary bench mark); TIN (Triangulated Irregular Network) ); XYZ are longitude, latitude, and elevation. 


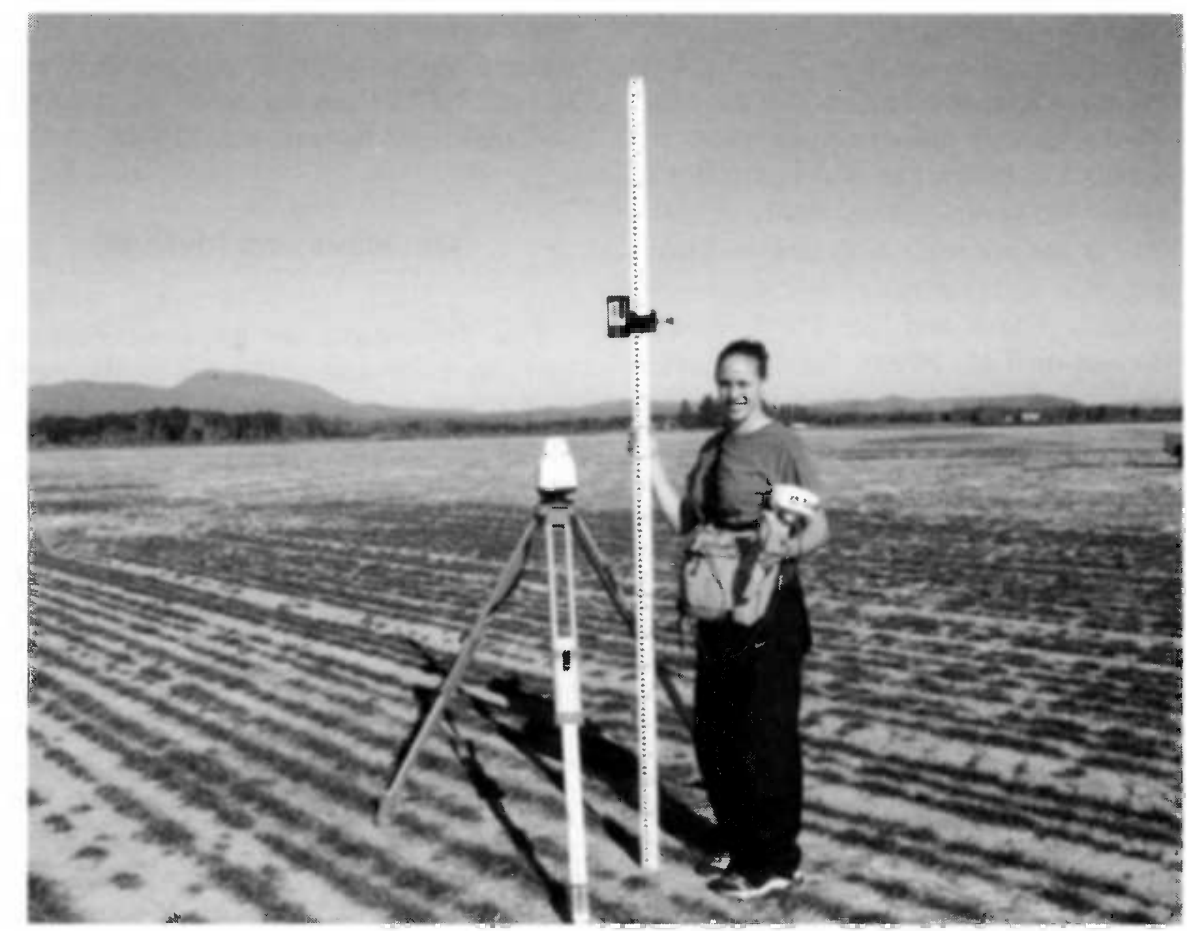

Fig. 1. Equipment used to generate highly accurate digital elevation models include a laser level and a sliding laser receiver attached to a leveling rod. In the horizontal mode, the laser level self levels via a wire-hung, air-damped compensator. The Pro Shot ${ }^{\circledR}$ L4 (Laser Reference, Inc.) laser level we used has a working radius of $230 \mathrm{~m}$, with a leveling accuracy of $1.6 \mathrm{~mm}$ per $30 \mathrm{~m}$.

equipment rental stores for approximately $\$ 40$ per day. Necessary components are described in Table 2.

If it is important to determine the true elevation of the laser for reasons other than creating a relative digital elevation model, it is necessary to either find an existing National Geodetic Survey (NGS) ground control point or establish a temporary bench mark. The National Geodetic Survey maintains ground control points represented by survey monuments. Locations of these can be obtained from point, it is advantageous to locate the temporary bench mark at a location where vehicles or vandals will not damage it and it can be used in the future. It should be placed so it is close to and visible from the area to be surveyed. For most of our work, we are interested in vertical position relative to the elevation of the temporary bench mark. In this case, we position the temporary bench mark by collecting numerous coarse-acquisition code differential global positioning system fixes with the global positioning system antenna in a static position on a tripod at a set height above the point. Our coarse-acquisition code differential global positioning system records a position every second and we normally record data for an hour or more to achieve accuracy within $60 \mathrm{~cm}$. If we want to define absolute elevations of the area being surveyed, we will position the temporary bench mark using either traditional survey techniques or carrier-phase differential global positioning system. Carrier-phase differential global positioning system requires 2 global positioning system units, a rover, and a local base station. Accuracies within $10 \mathrm{~cm}$ (Trimble Navigation 1996) are attainable with carrier-phase differential global positioning system processing by occupying a location for 30 minutes.

Once the temporary bench mark has been positioned, the laser level (source) is set in the area to be surveyed and the height of the laser above the reference point is measured with a leveling rod and laser receiver (Fig. 1). Our laser level has a working radius of $230 \mathrm{~m}$. We record the $\mathrm{X}, \mathrm{Y}$ location of the laser level with the differential global positioning system, and 2 additional pieces of information as comments in the data file: (1) the laser height identification code, which includes the date and sequence number of each particular setup of the laser level, and (2) the elevation of the laser beam. The elevation of the rotating laser is determined by measuring its height above the temporary bench mark with a laser receiver attached to a leveling rod then adding the elevation of the temporary bench mark. This information will be used to determine the elevation of each point and helps us organize data during office processing.

\section{Grid Sampling}

Once the laser level has been set up on a ground-control position, it rotates $360^{\circ}$ automatically and the 2 -person crew moves across the area to be surveyed, stopping to record differential global positioning system points across the terrain. At 
each sample location the person carrying the differential global positioning system records a northing (latitude or $\mathrm{Y}$ ) and easting (longitude or $\mathrm{X}$ ) coordinate. The second person adjusts the height of the electronic laser receiver on the calibrated leveling rod to capture the rotating laser beam and measures the height of the laser beam above the ground. This height is entered into the differential global positioning system data logger as a comment. A 2-person crew can record a location in approximately 25 seconds plus walking time. The crew would typically pace across the landscape in a grid pattern to systematically sample the field. It is important that they also sample other features of interest, such as hilltops and low spots as well as 'break lines' along drainage ways and ridges. To ensure that areas are adequately sampled, each point is marked with foam that persists long enough to finish a job. The quality of the digital elevation model will be a function of: (1) how many points are obtained; and (2) how the points are positioned (Clark and Lee 1998). As Clark and Lee (1998) point out "the procedure requires good judgment on the part of the surveyor, and is essential to obtaining a good topographic map."

On level, open terrain without brush or other obstructions, 16 ha can be measured from a single, central, laser location. For larger areas, we back-shoot from a new instrument location to the original temporary bench mark reference point. Since the elevation data is referenced to the temporary bench mark or ground control points, data can be collected over an extended time, as long as the temporary bench mark remains in place. Because the rotating laser beam sweeps $360^{\circ}$, more than 1 team can collect data at the same time. We have sampled agronomic fields, wetlands, and research plots using this technique. We collected the data necessary to map a 35ha grass seed field on a 20 -m grid pattern (1204 sample points) with 1 team in 24 hours.

\section{Office Processing}

In the office we differentially correct the global positioning system data with data from a local base station. We then export data to a spreadsheet program with each worksheet containing all data collected while the laser was at 1 location and height. Ground elevation is calculated for each sample point by subtracting the laser beam-to-ground distance (comment value in the global positioning system data logger) from the elevation of the laser beam that was determined from the temporary

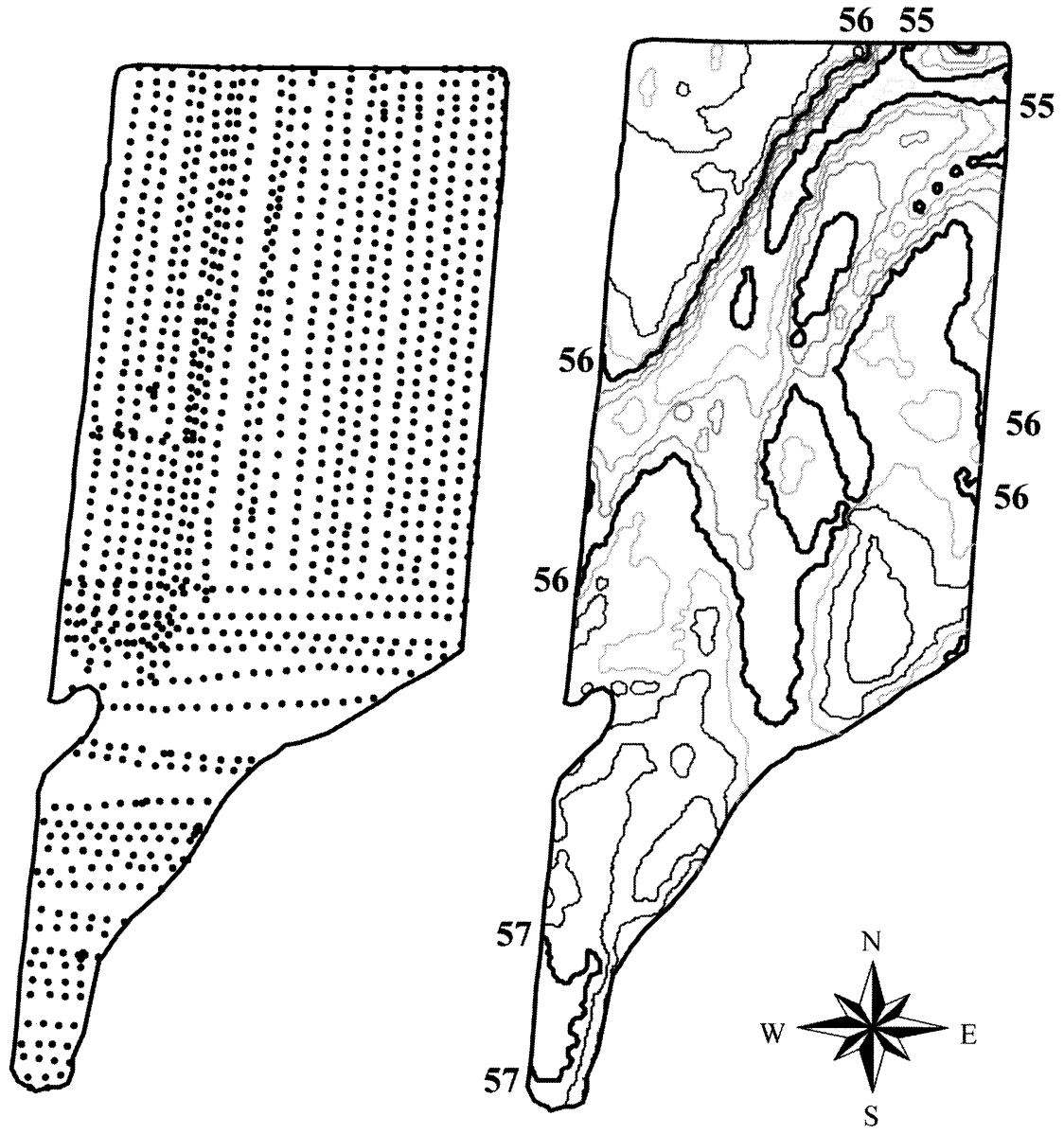

Fig. 2. Sample locations are depicted by the dots on the image of the field on the left. A contour map of the field, which was created by interpolation between sample locations, is shown on the right. Numbers are meters above ellipsoid (approximately above sea level). Note both within field variability and a general increase in elevation from north to south.

bench mark. Interpolation of a digital elevation model from point data is accomplished with any of the numerous commercial geographic information system software packages (ERDAS ${ }^{\circledR}$, IDRISI ${ }^{\circledR}$, Rockworks ${ }^{\circledR}$, ArcView ${ }^{\circledR}$ ArcGIS ${ }^{\circledR}$, etc.). The sampling pattern and resulting contour map of a 76-ha field, sampled with 2181 points, is shown in Figure 2.

\section{Limitations}

This technique was developed for measuring land with gently rolling topography, such as found in agronomic fields, wetlands, and research plots. Since X, Y coordinates may have a root mean square error of 50 to $100 \mathrm{~cm}$, it is not appropriate for short, deep cut-banks or short, steep escarpments where the cut face must be precisely positioned. Because the leveling rod and receiver unit has a working height from near ground level to $5 \mathrm{~m}$, rugged land can require frequent repositioning of the laser level, which reduces efficiency and increases costs. Shrubs and trees that block either the laser beam or reception of NAVSTAR satellite signals limit application of our technique as do weather conditions such as fog, rain, or excessive dust that absorb the laser beam and reduce the working radius of the laser level. For large fields or extensive areas, the labor cost of our technique can be high and using carrier-phase differential global positioning system technology becomes more attractive.

This procedure is intended to generate topographic models for agricultural and ecological interpretation. It is not appropriate for legal definition of floodplains, property boundaries, etc., which would require professional surveyors.

\section{Cost}

Assuming possession of a differential global positioning system and geographical information system/Image processing software, the cost of acquiring the field 
data and producing a topographic map are salary for 2 technicians and rental of the laser level. Spring 2002 cost of traditional surveying methods for the 35 -ha field described above was $\$ 2000$ to $\$ 2500$ (professional surveyors bids). Our cost, assuming $\$ 15$ per hour labor cost, was $\$ 720$ for field time plus $\$ 120$ laser rental, plus 6 hours computer processing time for a total of $\$ 930$.

\section{Conclusion}

The technique described above allows researchers and others to create high-resolution digital elevation models in a costeffective fashion. This method is suitable for research fields, wetlands, and experimental plots. The digital elevation model can be used to help explain patterns of vegetation, yield, and soils; and to help elucidate the role of topography on ecological processes.

\section{References}

Brady, N.C. and R.R. Weil. 2001. The Nature and properties of soils. $13^{\text {th }}$ edition. Prentice Hall, Upper Saddle River, N.J.
Bakhsh, A., T.S. Colvin, D.B. Jaynes, R.S. Kanwar, and U.S. Tim. 2000. Using soil attributes and GIS for interpretation of spatial variability in yields. Trans. Amer. Soc. Agr. Eng. 43:819-828.

Brooks, K.N., P.F. Ffolliott, H.M. Gregersen, and L.F. DeBano. 1997. Hydrology and the management of watersheds. Second edition. Iowa State Univ. Press, Ames, Iowa.

Clark, R.L. and R. Lee. 1998. Development of topographic maps for precision farming with kinematic GPS. Trans. Amer. Soc. Agr. Eng. 41:909-916.

Johansen, D.P., D.E. Clay, C.G. Carlson, K.W. Stange, S.A. Clay, D.D. Malo, and J.A. Schumacher. 2001. Vertical accuracy of two differentially corrected global positioning satellite systems. J. Soil and Water Conservattion 56:198-201.

Leica Geosystems AG. 1999. GPS Surveying - system 500. Leica Geosystems AG. Heerbrugg, Switzerland.

National Geodetic Survey. 1996. Data sheets on CD-ROM for the Western United States and Pacific Territories: AK, CA, HI, ID, OR, WA, and Pacific Territories. Silver Spring, Md.

National Mapping Division, U.S. Geological Survey. 1998. National Mapping Program Technical Instructions: Standards for Digital Elevation Models. Version 01/1998. Silver Spring, Md.
Stoeckel D.M. and M.S. Miller-Goodman. 2001. Seasonal nutrient dynamics of forested floodplain soil influenced by microtopography and depth. Soil Sci. Soc. Amer. J. 65:922-931.

Sumpter, C.W. and G.W. Asher. 1994. Realtime kinematic GPS for cadastral surveys. Proc. Amer. Congr. on Surv. and Mapping. Amer. Soc. for Photogrammetry and Remote Sensing Int. Meeting 1994. Reno, Nev.

Trimble Navigation Ltd. 1996. Trimble Pathfinder Office $^{\mathrm{TM}}$, Software Reference Guide. Trimble Navigation Ltd., Sunnyvale, Calif

Trimble Navigation Ltd. 2001a. GPS pathfinder systems. Trimble Navigation Limited. Sunnyvale, Calif.

Trimble Navigation Ltd. 2001b. Trimble 5700 Receiver. Trimble Navigation Engineering and Construction. Dayton, Ohio.

Young, F.J. and R.D. Hammer. 2000. Soillandform relationships on a loess-mantled upland landscape in Missouri. Soil Sci. Soc. Amer. J. 64:1443-1454. 